Florette Cohen Abady

\title{
The Psychology of Modern Antisemitism: Theory, Research, and Methodology
}

The term "Antisemitism" was coined by Wilhelm Marr in 1879 in Germany in order to provide a more intellectually acceptable veneer to the crude and blunt "hatred of Jews." "To date, "antisemitism" continues to be used to describe Jew-hatred. ${ }^{2}$ Ironically (given the origin of the term), some Arab/Muslim commentators have complained that Jews have inappropriately expropriated the term "antisemitism," arguing that antisemitism technically also refers to hatred of Arabs, who are "Semites" as well. ${ }^{3}$ Nonetheless, the term antisemitism commonly refers solely to prejudice against Jews.

Given Jews' relative success in the world since the end of World War II, it is reasonable to wonder why a conference dedicated to understanding antisemitism is even necessary. It is necessary because current world events demonstrate that antisemitism is far from dead; it may actually be in its prime. Blatant antisemitism is easily recognizable. Physical attacks on persons and property, verbal slurs, and discrimination reveal obvious prejudice. While Jews have long been subject to such forms of discrimination throughout the diaspora, it was hoped that it waned since WWII, unfortunately this is no longer the case, and Jews are once again being victimized by high levels of blatant antisemitism in much of the world.

\section{Antisemitism Research}

Although antisemitism was a major field of scientific study among psychologists between the 1930s and mid 1950s, ${ }^{4}$ research dropped off sharply after the 1960's.

1 Cf. M. Zimmermann, Wilhelm Marr: The Patriarch of Anti-semitism (New York: Oxford University Press, 1986).

2 Cf. M. Ostow, “A Contribution to the Study of Antisemitism," in Error without Trial: Psychological Research on Antisemitism, ed. W. Bergmann (Berlin: de Gruyter, 1988), 52-76.

3 Cf. e.g. I. Nafie, “Israel's anti-Semitism,” Al-Ahram Weekly Online, November 20-26, 2003, http://weekly.ahram.org.eg/2003/665/op1.htm.

4 Cf. T. W. Adorno, E. Frenkel-Brunswik, D.J. Levinson, and R. N. Sanford, The Authoritarian Personality (New York: Harper \& Brothers, 1950); L. Berkowitz, and D. S. Holmes, "A Further Investigation of Hostility Generalization to Disliked Objects," Journal of Personality 28 (December 1960): 427-42; L. Festinger, "Informal Social Communication," Psychological Review 57, no. 5

Ә OpenAccess. () 2019 Florette Cohen Abady, published by De Gruyter. (cc) BY-NC-ND This work is licensed under the Creative Commons Attribution-NonCommercial-NoDerivatives 4.0 License. 
In its early years as a discipline, social psychology investigated the relationship between personal attributes and social behavior regarding antisemitic attitudes in Europe, Russia, and the United States. ${ }^{5}$ Effects of changes in roles on individual's attitudes were tested using films such as a Gentleman's Agreement ${ }^{6}$ as primes, in which experimental participants were more likely to show reductions in the expression of anti-Semitic sentiments. Correlations between status, authoritarianism, and antisemitism were demonstrated as well. ${ }^{7}$

By the late 1950s and early 1960s, however, social psychological interest in antisemitism began to decline. The shock of the Nazi war crimes wore off, the remaining Jews became progressively more accepted and assimilated into the western European and North American democracies, and, at least in America, the Black Civil Rights Movement largely defined the 1950s and early 1960s. Antisemitism studies waned and Black-White racial studies concerning stereotypes, prejudice, and discrimination became a major topic. ${ }^{8}$ Interestingly, the common psychological phenomena underlying all prejudice should help to explain antisemitism.

Prejudice is an attitude and thus has affective, behavioral, and cognitive components, which may be referred to as the ABC's of prejudice. ${ }^{9}$ The ABC's of prejudice have been experienced by Jews throughout history.

\section{Prejudice: The Affective Component}

An understanding of prejudice towards Jews begins with an investigation of what social psychologists refer to as the affective component. Affect (commonly thought of as emotions in laymen's terms) begins with an attitude or evaluation

(1950): 271-82; D. J. Levinson, and R. N. Sanford, “A Scale for the Measurement of Anti-Semitism,” The Journal of Psychology 17, no. 2 (1944): 339-70.

5 Cf. Adorno, Frenkel-Brunswik, Levinson, and Sanford, The Authoritarian Personality; Levinson and Sanford "A Scale for Measurement”; N. C. Morse and F. H. Allport, "The Causation of antiSemitism: An Investigation of Seven Hypotheses," The Journal of Psychology: Interdisciplinary and Applied 34 (1952): 197-233.

6 L. Z. Hobson, Gentleman's Agreement (New York: Simon \& Schuster, 1947).

7 Cf. Adorno, Frenkel-Brunswik, Levinson, and Sanford, The Authoritarian Personality.

8 Cf. e.g. M. Rokeach and L. Mezei, "Race and Shared Belief as Factors in Social Choice," Science 151, no. 3707 (1966): 167-72; J. M. Jones, Prejudice and Racism (New York: McGraw-Hill, 1996).

9 Cf. S. J. Breckler, "Empirical Validation of Affect, Behavior, and Cognition as Distinct Components of Attitude," Journal of Personality and Social Psychology 47, no. 6 (1984): 1191-205. 
of an object ranging from extremely positive (love) to negative (hate). ${ }^{10} \mathrm{~A}$ negative affective/emotional response to an object is likely to cause a negative attitude towards that object. Additionally, emotions are automatically and unconsciously aroused. Because they are unconscious, the reason for the emotion is rarely recognizable or logically founded. As such, prejudice is defined as a hostile or negative attitude toward a distinguishable group of people, based solely on their membership in that group. The affective component of antisemitism would be the illogical statement, "I HATE Jews."

Antisemitic people direct their prejudice towards all Jews as a whole, ignoring individuating characteristics of members of Jewish communities. Often those who are the most antisemitic have never even encountered a Jew. As a young graduate student at Rutgers University, I mentored an undergraduate researcher in our Prejudice and Stereotypes lab who was shocked to find out that I was Jewish. He asked where my horns and tail were. He went on to explain that as a young boy, he was taught that Jews were demons who wore skullcaps or head coverings referred to in Yiddish as "yarmulkas" to hide their horns-Jews were to be feared, detested, and regarded as evil. Unfortunately, this student was not the first to recant tales of the old antisemitic motif, and I suspect he will not be the last. But why are such horrific pictures painted of Jews who were never seen? What psychological need do these images serve?

\section{Stereotypes: The Cognitive Component}

As thinking creatures, we all walk around with images in our minds of the world, its contents, and its inhabitants. Some images are flattering and some are outright grotesque. As children, we learn to understand the world around us by categorizing or grouping together similar objects of all sorts of things, such as inanimate objects (e.g. toys, clothes and furniture), food items (e.g. fruits and vegetables) and animals (e.g. dogs, fish and birds). ${ }^{11}$ Similarly, categorizing people into like groups enables us to easily and effectively simplify a complex world. ${ }^{12}$ In 1922, Journalist Walter Lippman penned the term stereotype to generalize essentially all members of a group of people with identical characteristics regardless of individuating differences among its members.

10 Cf. W. Wood, “Attitude Change: Persuasion and Social Influence," Annual Review of Psychology 51 (2000): 539-70.

11 Cf. M. B. Brewer and R. J. Brown, "Intergroup relations," in The Handbook of Social Psychology, ed. D. T. Gilbert, S. T. Fiske, and L. Gardner (New York: McGraw-Hill, 1998), 554-94.

12 Cf. G. W. Allport, The Nature of Prejudice (Cambridge: Perseus Books, 1954). 
Because Stereotyping is a cognitive process used to simplify the world around us, it is not always affectively charged and does not always lead to the act of discrimination. Some stereotypes may even be positive. Referring to Jews as clannish, hardworking, or smart in itself may not constitute antisemitism, unless every individual Jew encountered is subtly expected to be a perfect student. Negative stereotyping leading to blatant antisemitism may occur when all Jews are outright considered greedy and shady business people (see Matthew Baigell's The Implacable Urge to Defame for an early American history of Jewish stereotypes in the American Press). ${ }^{13}$ In a study conducted with Russian participants, Jews were rated higher on stereotypes for power (specifically, smart and show initiative) than their Chechen counterparts and lower for stereotypes of morality. ${ }^{14}$ Preconceived stereotypes in which all Jews are cheap, and greedy may affect behavior towards a specific Jew, regardless of whether the individual Jew possesses the stereotyped character trait.

\section{Discrimination: The Behavioral Component}

Stereotypical beliefs may result in discrimination, consensually defined among most social psychologists as an unjustified negative behavior toward members of a group based solely on their group membership. ${ }^{15}$ Antisemitic discrimination may range in its severity. On the most basic level, discriminatory, antisemitic behavior may be something as simple as exclusion from an exclusive golf club for being undesirable applicants. ${ }^{16}$ In the United States and in Europe, Jews are disproportionally victimized in bias crimes compared to other demographic groups. ${ }^{17}$

13 M. Baigell, The Implacable Urge to Defame: Cartoon Jews in the American Press, 1877-1935 (Syracuse: Syracuse University Press, 2017).

14 Cf. C. W. Leach, A. Minescu, E. Poppe, L. Hagendoorn, A. E. Abele, A. J. C. Cuddy, Ch. M. Judd, and V. Y. Yzerbyt, "Generality and Specificity in Stereotypes of Out-group Power and Benevolence: Views of Chechens and Jews in the Russian Federation," European Journal Of Social Psychology 38, no. 7 (December 2008): 1165-174.

15 Cf. L. M. Jackson, The Psychology of Prejudice: From Attitudes to Social Action (Washington: American Psychological Association, 2011).

16 Cf. D. Dee, “'There is no discrimination here, but the committee never elects Jews': Antisemitism in British Golf, 1894-1970,” Patterns Of Prejudice 47, no. 2 (May 2013): 117-38.

17 Cf. W. Cheng, W. Ickes, and J. B. Kenworthy, "The Phenomenon of Hate Crimes in the United States,” Journal Of Applied Social Psychology 43, no. 4 (2013): 761-94; P. Iganski, “Too Few Jews to Count? Police Monitoring of Hate Crime against Jews in the United Kingdom," American Be- 


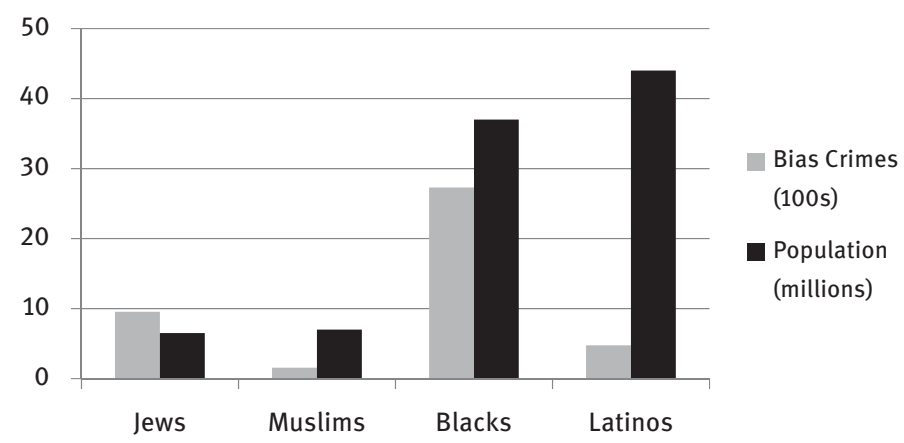

Figure 1. Jews are Disproportionately Victimized by Hate Crimes.

On the extreme end of the spectrum, historical events such as the Crusades, the Inquisition, and the Holocaust led to Jews being burned at the stake, tortured, expelled, and mass murdered simply because they were Jews. ${ }^{18}$

In the late 1940 s and early 1950s, novels and movies such as A Gentleman's Agreement starring Gregory Peck highlighted antisemitic discrimination in the United Stated. The plot set in post-World War II New York City portrayed a non-Jewish reporter, Phil Green, pretending to be Jewish in order to research antisemitism. As a Jew, he faced job discrimination, housing discrimination, and his son was bullied at school. It was a revolutionary motion picture in its time for tackling the then taboo theme of antisemitism. In the US, the Holocaust was still fresh in people's minds and it was unconscionable to believe that Americans harbored antisemitic prejudice. The book made the New York Times Best Sellers List and the movie won three Academy Awards. Critics are still hailing it as a "must watch" today for cleverly combining a social psychological experiment with a powerful social message. ${ }^{19}$ The outcome depicted in the movie was consistent with results of several experiments on interpersonal discrimination. ${ }^{20}$

havioral Scientist 51, no. 2 (October 2007): 232-45; U.S. Census, "Law Enforcement, Courts, and Prisons,” accessed June 25, 2018, http://www.census.gov/prod/2004pubs/04statab/law.pdf.

18 Cf. A. Mohl, "The Evolution of Anti-Semitism: Historical and Psychological Roots," The Journal Of Psychohistory 39, no. 2 (2011): 115-28.

19 Cf. P. Bradshaw, "My Favorite Best Picture Oscar Winner: Gentleman's Agreement," The Guardian, February 15, 2017, https://www.theguardian.com/film/2017/feb/15/best-picture-oscarwinners-gentlemans-agreement-1947.

20 Cf. M. R. Hebl, J. B. Foster, L. M. Mannix, and J. F. Dovidio, "Formal and Interpersonal Discrimination: A Field Study of Bias Toward Homosexual Applicants," Personality and Social Psychology Bulletin 28, no. 6 (June 2002): 815-25. 
Yet even after the obvious nature of antisemitism was brought to the forefront, antisemitism continues to exist and some question whether it has grown stronger. Can we put an end to antisemitism?

\section{Understanding Antisemitic Thinking}

A possible explanation for prejudice and antisemitism in particular is that it is a learned process (brought down from generation to generation) and therefore the inevitable byproduct of information processing. As previously discussed, the most basic cognitive processes include categorization and group creation. Once we have the established mental category Jews (no different for cognitive purposes than the mental category fruit), we group all members of the Jewish religion, race, and nation into the simple group Jews while at the same time downplaying individual differences between Jewish group members and exaggerating differences between Jews and non-Jews. Social categorization by nature creates an us-versus-them-scenario, or what social psychologists refer to as an in-group bias, in which we prefer members of their own group, referred to as the in-group (those similar to us) over members of other groups, referred to as the out-group (anyone considered different from us-them).

For centuries, Jews were considered social pariahs. Throughout Europe, Jews were enclosed behind ghetto walls and often forced to wear distinctive clothing thereby creating an obviously different social group. Indeed, research revealed that European participants even tended to agree with negative antisemitic stereotypes presented in abstract rather than concrete terms, but this was not the case for negative stereotypes of other groups. ${ }^{21}$ Research tends to support theories of in-group bias suggesting that Jews over centuries have become the perennial out-group.

According to Henri Tajfel, in-group bias is psychologically motivated by the need for self-esteem. Tajfel created the minimal group paradigm to study this phenomenon. He arbitrarily grouped random strangers into two groups and assigned each group a name. This simple grouping criterion was enough to induce in-group bias among group members. Group members showed a preference for their own group members through higher ratings and rewards. Additionally, social categorization leads to what social psychologists refer to as out-group homogeneity, or the perception that those in the out-group are more similar to each

21 Cf. A. Maass, F. Montalcini, and E. Biciotti, “On the (Dis-)confirmability of Stereotypic Attributes,” European Journal Of Social Psychology 28, no. 3 (May 1998): 383-402. 
other than they really are, as well as more similar than the members of the ingroup are (i.e., the belief that "they're all alike"). ${ }^{22}$ In his book Anti-Semite and Jew, Jean-Paul Sartre presents a scenario in which a non-Jew felt she was cheated by a Jewish furrier and as a result disliked all Jews in general rather that that particular Jew (or even furriers as a group). ${ }^{23}$ Sartre's example demonstrates a collapse of logic. With logic gone, it becomes very difficult if not impossible to get a deep-seated antisemite to change his or her mind.

Allport presents a debate between a steadfast antisemite and a non-antisemite (for lack of a better term) in which the non-antisemite presents the charitable nature of Jews; the antisemite, despite repeated attempts to the contrary, clings to his convictions that Jews are cheap, selfish people with shady business practices. $^{24}$ This may be the case for one of two reasons: first, antisemitism is not logical; it is emotional. Attitudes stemming from antisemitic emotion are no longer reasonable, causing a prejudiced person to distort challenges to their beliefs. ${ }^{25}$ Second, an ardent antisemite has such strongly imprinted stereotypes of Jews that all they can pay attention to is the information consistent with their antisemitic beliefs, at which point the stereotypes are invulnerable to change. ${ }^{26}$ While these stereotypes may not be as blatantly expressed today, they continue to persist. Terms like “don't Jew me down” are still heard during bargaining processes even among elite businessmen, and these stereotypes to a degree have become culturally recognizable and acceptable. ${ }^{27}$

Research reveals that these stereotypes are automatic even if one considers him or herself a non-prejudiced person. ${ }^{28}$ Because stereotypical and prejudiced beliefs are automatic, they then affect information processing. When we encounter a Jew, commonly held Jewish stereotypes are automatically triggered. Once those old stereotypes are activated in our minds, then it is up to us to decide whether or not to accept the stereotype and allow it to affect our judgement. Research on automatic and controlled prejudice has shown that non-Jewish partic-

22 Cf. H. Taifel, “Social Psychology of Intergroup Relations,” Annual Reviews of Psychology 33, no. 1 (1982): 1-39.

23 Cf. J.-P. Sartre, Anti-Semite and Jew (New York: Schocken Press, 1948).

24 Cf. Allport, The Nature of Prejudice.

25 Cf. N. W. Ackerman and M. Jahoda, Anti-Semitism and Emotional Disorder: A Psychoanalytic Interpretation (New York: Harper \& Brothers, 1950).

26 Cf. Ch. Y. Glock, and R. Stark, Christian Beliefs and Anti-Semitism (New York: Harper and Row, 1966).

27 Cf. P. G. Devine, and A. J. Elliot, “Are Racial Stereotypes Really Fading? The Princeton Trilogy Revisited,” Personality and Social Psychology Bulletin 21 (1995): 1139-150.

28 Cf. P. G. Devine, "Stereotypes and prejudice: Their Automatic and Controlled Components," Journal of Personality and Social Psychology 56, no. 1 (1989): 5-18. 
ipants administered stronger shocks to Jewish targets than non-Jewish targets only after they believed the Jewish targets spoke about them. This means that antisemitic stereotypes were activated, but they were only acted upon once the participant believed they were justified in doing so. ${ }^{29}$

Antisemitism is often automatic and unconscious. Research in terror management theory $\left(\mathrm{TMT}^{30}\right.$ ) proposes that many human activities unconsciously function to reduce the terror that comes from awareness of one's own mortality. Culture provides one way to manage death-related anxiety. It does so by providing worldviews that offer order, meaning, and permanence; by providing a set of standards of valued behavior that, if satisfied, provide self-esteem; and by promising protection and, ultimately, death transcendence to those who fulfill the standards of value. People therefore expend a great deal of effort maintaining their culturally-bestowed worldviews and defending them against threats.

Although adherents often experience their cultural worldviews as absolute reality, these are actually fragile social constructions requiring continual validation from others especially when confronted with reminders of mortality. This validation occurs mainly through the process of social consensus. Thus, the mere existence of others with similar worldviews (the in-group) bolsters people's faith in the validity of their own worldviews, thereby increasing the effectiveness of the worldviews as anxiety-buffers. Likewise, the mere existence of others with dissimilar worldviews (the out-group) threatens the people's faith in their own worldviews and undermines the effectiveness of the worldviews as anxiety-buffers. For these reasons, TMT provides a straightforward explanation for antisemitism (prejudice against a Jewish out-group). When focused on their own mortality, and in need of the protection their worldviews provide, non-Jews may become more hostile towards Jews, because Jews represent a challenge to their worldviews. Indeed early TMT studies revealed that after thoughts of death were brought into conscious awareness, non-Jewish participants liked non-Jewish targets more and Jewish targets less. More recent research replicated these findings and additionally showed that often people try to suppress their

29 Cf. R. W. Rogers and S. Prentice-Dunn, "Deindividuation and Anger-mediated Interracial Aggression: Unmasking Regressive Racism,” Journal of Personality and Social Psychology 41, no. 1 (July 1981): 63-73.

30 Cf. J. Greenberg, Sh. Solomon, and T. Pyszczynski, "Terror Management Theory of Self-esteem," in Handbook of Social and Clinical Psychology: The Health Perspective, ed. C.R. Snyder, and D. R. Forsyth (Elmsford: Pergamon, 1991), 21-40. 
antisemitic attitudes in order to appear unprejudiced and maintain a positive self-concept. ${ }^{31}$

Very often, in order to justify antisemitic attitudes, people may blame the victim and making what social psychologists refer to as dispositional attributions for their victimization; ${ }^{32}$ the victim's predicament is due to deficits in the victim's character. The belief is that if Jews have been the targets of antisemitism throughout history, then they probably did something to deserve it. The belief in a just world posits that people get what they deserve and deserve what they get. ${ }^{33}$

Beloved children's author and known antisemite Ronald Dahl was quoted as saying,

"There is a trait in the Jewish character that does provoke animosity [...] maybe it's a kind of lack of generosity towards non-Jews. I mean, there's always a reason why anti-anything crops up anywhere; even a stinker like Hitler didn't just pick on them for no reason [...] I mean, if you and I were in a line moving towards what we knew were gas chambers, I'd rather have a go at taking one of the guards with me; but they [the Jews] were always submissive." ${ }^{34}$

Psychologically, belief in a just world is a coping mechanism used to protect us from fears and worries by convincing ourselves that if we are good people, no harm will come to us. Unfortunately, belief in a just world leads to derogation of the victim and prejudice. If one believes that six million Jews perished in the Holocaust because of their own doing, they can be comforted in believing that something like that could never happen here to them.

\section{Prejudice and Economic Competition: Realistic Conflict Theory}

On a conscious and more obvious level, a main source of antisemitism could be accounted for by economic competition and realistic conflict theory. Whenever Jews have been given a reasonable degree of freedom that approaches or equals

31 Cf. F. Cohen, L. Jussim, K. D. Harber, and G. Bhasin, "Modern Anti-Semitism and Anti-Israeli Attitudes," Journal of Personality and Social Psychology 97, no. 2 (2009): 290-306.

32 Cf. M. Lerner and D. T. Miller, "Just World Research and the Attribution Process: Looking Back and Ahead," Psychological Bulletin 85, no. 5 (1978): 1030-51.

33 Cf. M. Lerner, The Belief in a Just World: A Fundamental Decision (New York: Plenum, 1980). 34 M. Oppenheim, "Roald Dahl after 100 Years: Remembering Beloved Author's Forgotten AntiSemitic Past,” Independent Minds, September 13, 2016, https://www.independent.co.uk/news/ people/roald-dahl-antisemitic-100-years-remembering-author-forgotten-past-a7254266.html. 
that of other citizens, they have achieved economic and professional success at extraordinarily high levels (e.g., Spanish Jews under medieval Islamic rule, Polish Jews in the sixteenth century, ${ }^{35}$ the Jews of Europe after emancipation in the nineteenth century, ${ }^{36}$ and modern American Jews).

Furthermore, in the modern world, Jews have had an extraordinary record of intellectual success. Jews represent less than one half of one percent of the world population, yet of the 750 Nobel Prizes awarded between 1901 and 2006, 158 (21 percent) went to Jews. ${ }^{37}$ Although Jews constitute less than 3 percent of the US population they disproportionately enter the university system and professions, ${ }^{38}$ and, as a result, Jews have substantially higher incomes than do other groups. ${ }^{39}$

Such disproportionate representation can be a cause of suspicion and envy.

Realistic Conflict Theory posits that limited resources lead to increased conflict between competing groups thereby resulting in increased prejudice and discrimination..$^{40}$ Several historical studies document that prejudice, discrimination, and violence against out-group members is positively correlated with the scarcity of jobs or other resources..$^{41}$ Correlational and experimental data exist that support group conflict theory. For example, Hovland and Sears found a significant $(\mathrm{r}=-.72)$ correlation between the price of cotton and the number of lynchings of blacks in the South from 1882 to $1930 .{ }^{42}$ Classic scientific experiments conducted by Şerif et al. known as the "Robber's Cave" experiment pitted two randomly assigned groups of twelve-year-old boys at a summer camp, the Eagles or the Rattlers. Group cohesiveness and group competitiveness developed causing hostility between the two groups to rapidly escalate demonstrating how

35 Cf. J. Spunberg, "History of the Jews in Poland," accessed June 5, 2018, http://www.berdichev. org/history_of_the_jews_in_poland.htm

36 Cf. M. Weber, Protestant Ethic and the Spirit of Capitalism (New York: Scribner, 1958).

37 Cf. https://www.jewishvirtuallibrary.org/jewish-nobel-prize-laureates.

38 Cf. Hillel International: The Jewish Foundation for Campus Life, https://www.hillel.org/. 39 Cf. Ch. Smith and R. Faris. "Socioeconomic Inequality in the American Religious System: An Update and Assessment," Journal for the Scientific Study of Religion 44 (2005): 95-104.

40 Cf. M. Şerif, Group Conflict and Cooperation: Their Social Psychology (London: Routledge \& Kegan, 1966).

41 Cf. J. Dollard, "Hostility and Fear in Social Life," Social Forces 17, no. 1. (October 1938): 15-26; P. Jacobs and S. Landau, To Serve the Devil: Natives and Slaves (New York: Random House, 1971); D. Kohl, "The Presentation of 'Self' and 'Other' in Nazi Propaganda," Psychology and Society 4, no. 1 (2011): 7-26.

42 Cf. C. I. Hovland and R. R. Sears, "Minor Studies in Aggression: VI. Correlation of Lynchings with Economic Indices,” Journal of Psychology 9 (1940): 301-10. 
easily conflict and discrimination can escalate from what were previously nonexisting groups. ${ }^{43}$

In the 1930s, the world economy sank into the Great Depression. In Germany, in particular the economic situation was grim, yet most Jews fared quite well and appeared to be employed in good jobs. This could have contributed to animosity between German Jews and non-Jews competing for scarce resources, as the preWorld War II sentiment in Germany was the Jews are stealing my business, my job and the future of my country.

Historical research also found that antisemitism rises with economic downturn. During the last financial crisis, 31 percent of European adults polled blamed Jews in the financial industry for the economic meltdown; and 40 percent of European adults polled believed that Jews have an over-abundance of power in the business world. ${ }^{44}$ An extreme case of realistic conflict theory is scapegoating, or the tendency for individuals, when frustrated or unhappy, to displace aggression onto those groups who are relatively powerless, disliked, and visible. Often, scapegoating occurs when people are frustrated (economically or politically), but there is no clear target to blame the frustration on. It may occur even in the absence of direct competition..$^{45}$ Jews are often the target of scapegoating because of their visibility and historical weakness. For centuries, they were few in numbers, defenseless, and had no homeland of their own.

Research subjecting antisemitic and non-antisemitic participants to a great deal of frustration revealed that antisemitic participants assigned to write stories about pictures containing Jewish names wrote stories in which more aggressive actions were directed towards them, where those assigned to pictures with nonJewish names did not (results did not significantly differ for non-antisemitic participants). ${ }^{46}$

43 Cf. M. Şerif, et al., The Robbers Cave Experiment: Intergroup Conflict and Cooperation (Middletown: Wesleyan University Press, 1961).

44 Cf. Anti-Defamation League, "Attitudes Toward Jews and the Middle East in Five European Countries,” issued May 2007. https://www.adl.org/sites/default/files/documents/assets/pdf/is rael-international/European_Attitudes_Survey_May_2007.pdf; N. Mozgovaya, "Poll: 31\% of Europeans Blame Jews for Global Financial Crisis," Haaretz, February 10, 2009, https://www. haaretz.com/1.5073513.

45 Cf. Allport, The Nature of Prejudice; P. S. Glick, "Choice of Scapegoats," in On the Nature of Prejudice: Fifty Years after Allport, ed. J. F. Dovidio, P. S. Glick, and L. A. Rudman (Malden: Blackwell, 2005), 244-61.

46 Cf. D. Weatherley, “Antisemitism and the Expression of Fantasy Aggression,” The Journal of Abnormal and Social Psychology 62, no. 2 (1961): 454-57. 


\section{Normative Conformity}

Human beings are social creatures in need of love and acceptance by those around them. Explicit and implicit socialization provides the norms our culture is governed by. In order to be accepted, we conform to the standards of our culture. Very often, stereotypes and prejudiced attitudes are ingrained in those cultural norms making conformity very dangerous. Institutionalized prejudice refers to the concept that prejudiced attitudes, stereotypes, and discrimination are the norm; institutionalized antisemitism was the norm in European society and then in Nazi Germany at an alarming level. In this society, normative conformity led the German populace to go along with Hitler's plan to wipe out European Jewry in order to fulfill the regime's expectations and gain acceptance. Research reveals that people's prejudice and discrimination are subject to change when they move to an area with different norms. ${ }^{47}$ As such, while realistic conflict theory and institutionalized antisemitism help to explain the events of the Holocaust, they do little to explain the uptick in antisemitism today. What exactly is happening now?

\section{Modern Antisemitism}

Modern sensibilities discourage people from expressing prejudice against minority groups (see, e.g., Nelson's The Psychology of Prejudice ${ }^{48}$ for a review). For many people, detecting bigotry in themselves represents a threat to their own self-worth. ${ }^{49}$ As such, overt racism and sexism have gone underground, hidden from external social censure and even from one's own self-recognition. These attitudes are submerged but not necessarily dormant; rather they are expressed

47 Cf. T. F. Pettigrew, "Personality and Sociocultural Factors in Intergroup Attitudes: a Cross-national Comparison,” Journal of Conflict Resolution 2, no. 1 (March 1958): $29-42$.

48 T. D. Nelson, The Psychology of Prejudice (Boston: Allyn \& Bacon, 2002).

49 Cf. P. G. Devine, M. J. Montieth, J. R. Zuwerink, and A. J. Elliot, "Prejudice with and without Compunction," Journal of Personality and Social Psychology 60, no. 6 (1991): 817-30; D. G. Dutton and R. A. Lake, "Threat of Own Prejudice and Reverse Discrimination in Interracial Situations," Journal of Personality and Social Psychology 28, no. 1 (1973): 94-100; S. L. Gaertner and J. F. Dovidio, “The Aversive Form of Racism," in Prejudice, Discrimination, and Racism, ed. S. L. Gaertner and J. F. Dovidio (San Diego: Academic Press, 1986), 61-90; K. D. Harber, "Self-esteem and Affect as Information,” Personality and Social Psychology Bulletin 31, no. 2 (February 2005): 276-88; E. E. Jones et al., Social Stigma: The Psychology of Marked Relationships (New York: Freeman, 1984). 
through more socially acceptable guises in the form of modern racism and modern sexism. ${ }^{50}$

Classic antisemitism, like other forms of bigotry, has largely gone underground. Except for extreme hate groups, few in the democratic West explicitly advocate repressing, isolating, or harming Jews. What, then, might be a more socially acceptable avenue for expressing antisemitism? Opposition to Israel. This is not to equate anti-Israel views with antisemitism but instead to suggest that hostility toward Israel may provide a socially acceptable cover for hostility toward Jews in general.

This kind of camouflage is common practice in hostility towards other groups. For example, hostility to minorities or women can be hidden within opposition to affirmative action, even though some who oppose this policy are neither sexists nor racists. Research examining blatant and modern racism in Europe found that those who scored as racist on blatant and modern racism wanted to send immigrants back; while those who scored as nonracist on the blatant scale but racist on the subtle scale did not want to take action to send immigrants back; however they were also unwilling to support any actions to help improve their rights. ${ }^{51}$ In the same way, hostility toward Israel can serve as socially acceptable cover for antisemitism precisely because other critics of Israel have motives untainted by such bias.

Except among extreme hate groups that have been around seemingly forever, one rarely sees this type of blatant antisemitic rhetoric in the democratic west. Instead, one finds something far more subtle: Attempts to stigmatize, censure, and sanction Israel for acts and policies that cause far less harm than those of other countries. For example, British academic unions have periodically voted or considered voting to boycott Israel; and both British and American churches have voted or considered votes to divest from Israel. Given the at least comparable, and often far greater suffering and oppression perpetrated by regimes such as China, North Korea, Saudi Arabia, and Burma; given the "occupations" occurring in places such as Kashmir, Northern Ireland, and Tibet; and given the vastly greater death perpetrated in conflicts occurring in Chechnya, the Congo, Syria, and Sudan than in the Arab-Israeli conflicts, the failure of these same unions and churches to advocate for similar sanctions against other, non-Jewish coun-

50 Cf. J. B. McConahay, "Modern Racism, Ambivalence, and the Modern Racism Scale," in Prejudice, Discrimination, and Racism, ed. S. L. Gaertner and J. F. Dovidio (San Diego: Academic Press, 1986), 91-125; J. K. Swim et al., "Sexism and Racism: Old-fashioned and Modern Prejudices,” Journal of Personality and Social Psychology 68, no. 2 (1995): 199-214.

51 Cf. T. F. Pettigrew and R. W. Meertens, "Subtle and Blatant Prejudice in Western Europe," European Journal of Social Psychology, 25 (1995): 57-75. 
tries, at least raises the specter that the desire to punish Israel might spring from something other than deep and sincere concern for human rights.

\section{Does The United Nations Disproportionately Scrutinize Israel?}

Supporters of Israel have long claimed that the United Nation subjects Israel to standards and scrutiny that it rarely applies to other countries. ${ }^{52}$ Of course, partisans often see the world as biased against them, which raises the possibility that such complaints reflect the bias of those complaining rather than any real disproportion in the UN's treatment of Israel versus other countries. ${ }^{53}$ Therefore, archival study of UN records examining whether the UN really does pay disproportionate attention to Israel were quite telling. ${ }^{54}$

"Attention" and "disproportionate" were operationalized using the United Nations website to locate all human rights documents pertaining to any member country. "Attention" therefore was objectively and quantitatively defined as the total number of UN documents on Israel for the period 1990-2007. "Proportionate" was defined by comparing situations such as Israel constructing a security fence that unjustifiably cuts through Palestinian homes and communities with Saudi Arabia's denial of women the right to vote or drive or the human rights violations that occurred during Israel's 2006 war with Lebanon to Russia's 2008 war with Georgia, specifically the amount of civilian death inflicted as a result of war or government policy.

Civilian death, especially when intentional (as it is in many conflicts), is the ultimate human rights violation. Furthermore, numbers of dead are quantitative, objective, and readily comparable across countries, ethnicities, religions, and cultures. Conflicts were specifically chosen where estimates have converged within a fairly narrow range.

Israel was compared to conflicts occurring on five different continents and conflicts with widely varying degrees of civilian death in order to obtain a broad view of the relationship between civilian death and UN scrutiny.

52 Cf. e.g. "UN Security Council Resolution 1701," Haaretz, November 26, 2007, https://www. haaretz.com/1.4960375.

53 Cf. e.g. R. P. Vallone, L. Ross, and M. R. Lepper, "The Hostile Media Phenomenon: Biased Perception and Perceptions of Media Bias in Coverage of the Beirut Massacre," Journal of Personality and Social Psychology 49, no. 3 (1985): 577-85.

54 Cf. F. Cohen, L. Jussim, G. Bhasin, and E. R. Salib, "The New Anti-Semitism Israel Model: Real World Evidence and Experimental Tests," Conflict and Communication On-Line 10 (2011): $1-16$. 


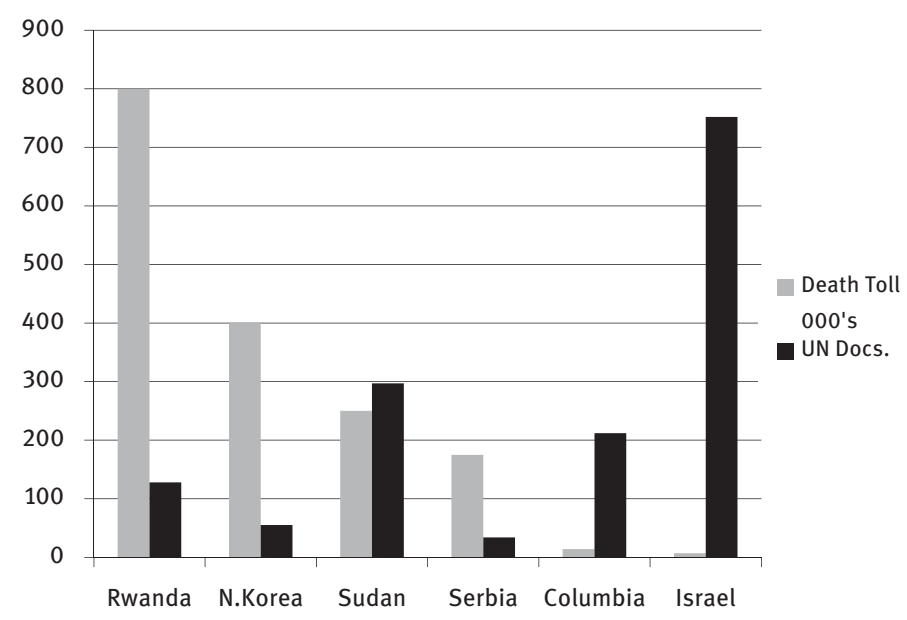

Figure 2. Does the UN Pay Disproportionate Attention to Israel? Numbers of UN Human Rights Documents versus Civilian Death, 1990-2007, in Israel and Five Other Countries.

Figure 2 summarizes the main results, which cover the period from 1990 2007. Several aspects of the data are quite striking: (1) Although the civilian death toll in this period is, in absolute terms, the lowest for Israel (and the figure for Israel includes Israeli civilian deaths as well as Arab civilian death); (2) The UN scrutiny is actually highest in absolute terms. On average, across the five comparison countries, the UN produced about 4 documents for every 10,000 civilian deaths (726 documents for 1,639,000 deaths). For Israel, the ratio is about 1 document for every 9 deaths (752 documents for 7100 deaths). Put differently, (1) The UN produced more documents regarding Israel than for all five of the comparison countries combined; and (2) the UN is about 239 times more likely to produce a document resulting from a civilian death involving Israel than it is to produce one for the other five countries examined.

These data, therefore, do not support the claim that supporters of Israel overstate or exaggerate the extent to which the UN disproportionately scrutinizes Israel. Instead, they support the claim that, in fact, the UN does indeed scrutinize the Israeli human rights situation far more than it does for other countries.

\section{Political Cartoons}

Numerous real world events seem to reflect the uniquely hostile reactions people often have towards Israel. For example, there are repeated initiatives to divest 
from Israel, to boycott Israeli scholars and universities, and to withdraw U.S. support from Israel on the basis of Israel's human rights records. However, the groups initiating these actions do not advocate similar sanctions against the many countries whose human rights records are much worse than is Israel's. This selectivity suggests that something other than (or in addition to) legitimate umbrage is informing anti-Israel sentiment.

Another disturbing example may be found in modern political cartoons in which Israel and Israelis are depicted as animals, insects, or cannibals.
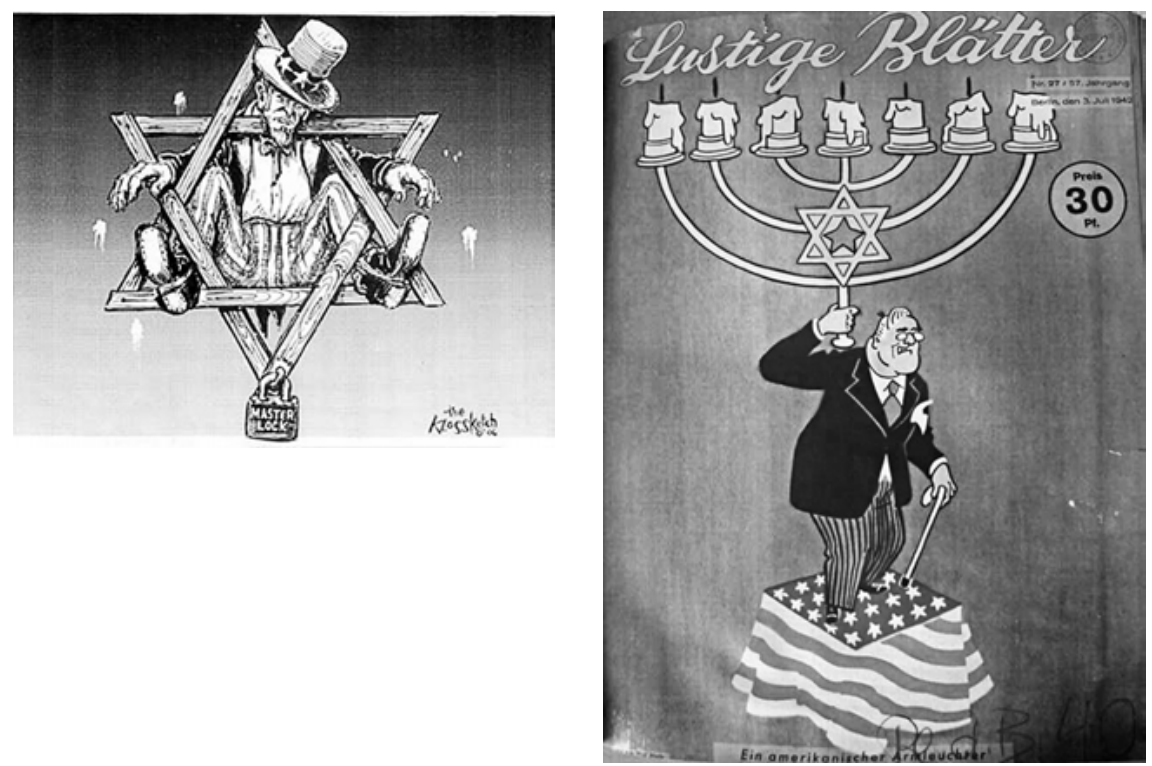

Image 1a. Modern Day Anti-Israel cartoon and its WWII Era Parallel. The US as a captive of the Jewish State. Caricature by John Closs for The Sacramento News \& Review August 3, 2006.

Source: www.rhymeswithright.mu.nu/images/ Image 1b. Modern Day Anti-Israel cartoon and its WWII Era Parallel. Lustige Blätter, Nr 27, 57. Jahrgang, 1942.

The caption reads "American Candelabra." The antisemitic theme suggests that Roosevelt is serving the Jews. JohnKlossAntiSemiticCartoon.jpg, accessed June 3, 2019. 


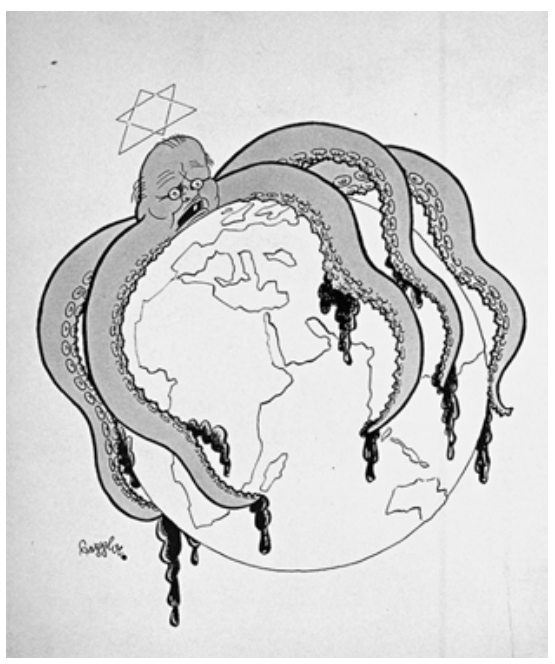

Image 2a. Modern Day Anti-Israel cartoon and its WWII Era Parallel Antisemitic cartoon by Seppla (Josef Plank), ca. 1938. An octopus with a Star of David over its head has its tentacles encompassing a globe.

Source: Library of Congress, courtesy of USHMM Photo Archives, Photograph Number: 73815.

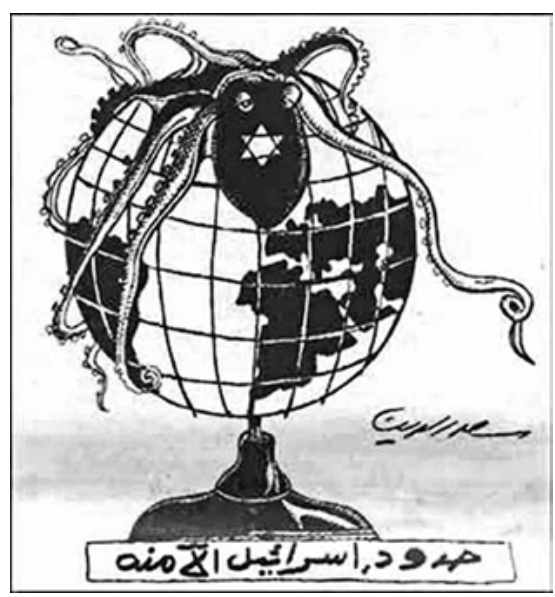

Image 2b. Modern Day Anti-Israel cartoon and its WWII Era Parallel Octopus bearing a Magen David (Star of David) clutching the globe in its tentacles. The caption reads "Secure borders for Israel.” Al-Ahram, May 25, 2002.

Source: http://www.antipasministries.com/ other/article225.htm, accessed June 3, 2019.

These cartoons are striking in several regards. First, on their face, they seem to reflect the virulent type of loathing that often characterizes deep-seated bigotries. Second, they were obtained from mainstream presses from a variety of countries (American, British, Egyptian). Third, many have a haunting similarity in substance, style, and motif to Nazi-era cartoons depicting Jews in a manner widely recognized as reflecting the most virulent form of antisemitism (also shown in the images above). I am not claiming that the authors of the modern cartoons are Nazi-sympathizers. The vile nature of these cartoons, however, does suggest that antisemitic attitudes may run wide and deep, and they raise the possibility that these cartoons reflect more than mere opposition to Israel and are consistent with the perspective suggesting that hostility to Israel may be expressed with such virulence that it is most likely powered, at least in part, by antisemitism. 


\section{Alternative Explanations}

When taken together, the evidence of hate crimes in the U.S., the evidence of rising international antisemitism gathered by a variety of organizations, the harsh bigoted rhetoric by some political leaders, churches, and unions considering sanctioning Israel but not countries with far worse human rights records, and the UN's bizarre record of attention to Israel strongly suggests that, after lying mostly dormant for a few decades immediately after World War II, antisemitism is on the march once again.

\section{The Situation Looks Grim: Possible Remedies}

Social psychological research suggests that, in a world bombarded by current events that heighten fear, threat, and group conflict (e.g., newspaper accounts of terrorism, war, natural disasters etc.), antisemitism is likely to continue. In France, religious Jews have been attacked, synagogues burned, and Jewish owned businesses stoned..$^{55}$ In many Middle Eastern countries, Israeli flag burning accompanied by shouts of "death to the Jewish infidels" and "Death to Israel" have become common practice. ${ }^{56}$

Additionally, despite Jewish success, most American Jews continue to see antisemitism as a problem, with some seeing antisemitism as a very serious problem. Research indicates that a multiplicity of factors affect perceptions of the seriousness of antisemitism. Those with a stronger sense of Jewish identity, lower income, and older people are more likely to see antisemitism as a very serious problem. Participants also view antisemitism as a more serious threat if they live in states with higher antisemitic incidents rates and when use of antisemitic terms in the news media increases. ${ }^{57}$ So what can be done?

55 Cf. D. Porat, R. Stauber, and R. Vago, eds., Anti-Semitism Worldwide 2003/4 (Tel Aviv: The Stephen Roth Institute, Tel Aviv University, 2005).

56 “Anti-Israel Protests Call For 'Death to Israel' \& 'Resistance'," Anti-Defamation League Blog, July 10, 2014, https://www.adl.org/blog/anti-israel-protests-call-for-death-to-israel-resistance. 57 Cf. J. E. Cohen, "Perceptions of Anti-Semitism among American Jews, 2000-05: A Survey Analysis,” Political Psychology 31, no. 1 (February 2010): 85-107. 


\section{Reducing Antisemitism}

Research on modern antisemitism specifically accounts for the possibility that Arab-Israeli relations have inspired a new manifestation of Jew hatred-virulent hostility to Israel. ${ }^{58}$ This political and ideological antisemitism provides a socially and intellectually acceptable modern disguise for sentiments that have roots going back at least 2,000 years. ${ }^{59}$ Once one recognizes modern antisemitism, it naturally leads to the question of what can be done to prevent it. Can models of general prejudice reduction be applied to antisemitism reduction as well? Would diversity training programs and prejudice reduction education help reduce both explicit and implicit antisemitism? The hope that prejudice can be reduced by education has proven naive. Change requires more.

\section{Intergroup Contact}

Social psychologists have long suggested that intergroup contact positively influences the quality of intergroup relations. ${ }^{60}$ Research has demonstrated that the amount of reported previous contact with outgroup members was generally related to a more positive perception of the outgroup. ${ }^{61}$ While contact per se may not be a sufficient condition for this effect, it is a potentially powerful tool for changing and ameliorating reciprocal perceptions between social groups. ${ }^{62}$

Two experiments conducted at Rutgers University demonstrated that students enrolled in a prejudice and conflict seminar instructed by an African-American professor showed decreased anti-Black biases at the end of the semester as compared with at the beginning of the semester. These effects were obtained for both explicit and implicit measures of prejudice, suggesting that multicultural

58 Cf. Cohen et al., "Modern Anti-Semitism."

59 Cf. B. Lewis, “The New Anti-Semitism," American Scholar 75 (2006): 25-36; J. Y. Gonen, A Psychohistory of Zionism (New York: New York American Library, 1975); H. C. Kelman, "Transforming the Relationship between Former Enemies: A Social Psychological Analysis," in After the Peace: Resistance And Reconciliations, ed. R. L. Rothstein (London: Lynne Renner, 1999), $193-205$.

60 Cf. Allport, The Nature of Prejudice; T. F. Pettigrew, "Intergroup Contact Theory," Annual Review of Psychology 49, no. 1 (1998) 68-85.

61 Cf. L. Castelli, L. De Amicis, and S. J. Sherman, "The Loyal Member Effect: On the Preference for Ingroup Members who Engage in Exclusive Relations with the Ingroup," Developmental Psychology 43, no. 6 (2007): 1347-59.

62 Cf. Pettigrew, "Intergroup Contact Theory." 
education can transform people's attitudes and beliefs at both the conscious and non-conscious level. ${ }^{63}$ However, at times increased contact is difficult to achieve. Often contact is avoided because of preexisting negative attitudes toward the outgroup. Additionally intergroup contact can be stressful and uncertain. ${ }^{64}$

Furthermore, integrating social situations such as the classroom or workplace does not necessarily guarantee increased contact between different groups or reduction in prejudicial attitudes. ${ }^{65}$ The Rudman et al. studies illustrated that students who voluntarily enrolled in diversity education showed a significant reduction in their implicit prejudice and stereotype scores, compared with control students. In other words, in order for contact to reduce prejudice, people must be open to intergroup interactions. ${ }^{66}$

Intergroup contact in which members of conflicting groups were open to dialogue has been shown not only to ease tensions between Israelis and Palestinians in the Middle East but also has led to strong friendships among members of the opposing groups. Palestinian students from the Hebron area and Israeli students from Bar-Ilan University participated in a series of meetings and activities lasting about four years. The meetings focused on commonalities between Islam and Judaism and eventuality led to several cooperative projects between the two groups. Participants reported positive reactions toward the meetings and attributed them to the discovery of commonalities in the other's religious culture. ${ }^{67}$

Awareness and prejudice rejection. Understanding our own biases is the first step to combating prejudice. Research indicates that people who become selfaware of their prejudiced responses attempt to regulate and reduce them because of the experience of negative self-directed affect. ${ }^{68}$ Recent research has demon-

63 Cf. L. A. Rudman, R. D. Ashmore, and M. L. Gary, “'Unlearning’ Automatic Biases: The Malleability of Implicit Prejudice and Stereotypes," Journal of Personality and Social Psychology 81, no. 5 (2001): $856-68$.

64 Cf. J. Blascovich, W. B. Mendes, S. B. Hunter, B. Lickel, and N. Kowai-Bell, "Perceiver Threat in Social Interactions with Stigmatized Others," Journal of Personality and Social Psychology 80, no. 2 (2001): 253-67; J. A. Richeson, and J. N. Shelton, "When Prejudice Does Not Pay: Effects of Interracial Contact on Executive Function,” Psychological Science 14, no. 3 (May 2003): 287-90. 65 Cf. J. Dixon, and K. Durrheim, "Contact and the Ecology of Racial Division: Some Varieties of Informal Segregation,” British Journal of Social Psychology 42, no. 1 (March 2003): 1-23; H. B. Gerard and N. Miller, School Desegregation: A Long-Term Study (New York: Plenum, 1975).

66 Cf. Rudman et al., "'Unlearning’ Automatic Biases.”

67 Cf. B. Mollov, "The Role of Religion in Conflict Resolution: An Israeli-Palestinian Student Dialogue,” Jerusalem Letter / Viewpoints 404 (April 1999): 1-6.

68 Cf. e.g., M. J. Monteith, "Self-regulation of Prejudiced Responses: Implications for Progress in Prejudice Reduction Efforts,” Journal of Personality and Social Psychology 65, no. 3 (1993): 469-85; M. J. Monteith, L. Ashburn-Nardo, C. I. Voils, and A. M. Czopp, "Putting the Brakes 
strated that confrontations of racial bias successfully reduced the likelihood of biased responses in a later experimental task. Thus, confrontations from others are likely to be effective to the extent that feelings such as guilt and self-criticism are elicited. ${ }^{69}$

Understanding the role of unconscious death threats in antisemitism. Educating people regarding the potentially harmful effects resulting from reminders of death (that are so common in daily life) and incorporating this education into established prejudice reduction programs could aid intergroup relations, fight antisemitism, and assist in the battle of general prejudice. As people recognize that antisemitism is, in part, a defense aimed at repressing death related anxieties, they may find other means to assuage their terror and protect against it. When people were instructed to think logically, negative mortality salience effects disappeared. ${ }^{70}$ Defense against anxiety need not come at the price of intolerance towards others. Perhaps such animosities may be directed towards more legitimate and inanimate targets, such as poverty, illness, ignorance, and conflict resolution.

Recent TMT research has demonstrated that mortality salience increases a need for heroes. After 9/11, Americans demonstrated great appreciation for police officers and firefighters who risked and even gave their lives to protect us. Additionally, many Americans behaved in altruistic manners (e.g., many gave blood, donated to police, fire fighters, and other 9/11-related charities). Thus, MS in conjunction with institutionalized prejudice reduction programs can indeed be redirected toward those who exemplify cultural values, act benevolently, or risk their own well-being to help others rather than intolerance.

Florette Cohen is Associate Professor for Social Psychology at CUNY College of Staten Island. She received her Ph.D. from the Social Psychology program at Rutgers University-New Brunswick in 2008. Her most recent line of research demonstrates that people who are reminded of their own death (mortality salience) respond by reaffirming their core values and beliefs, making their expressions of these more intense or more extreme. The mortality salience paradigm may be ap-

on Prejudice: On the Development and Operation of Cues for Control," Journal of Personality and Social Psychology 83, no. 5 (2002): 1029-50.

69 Cf. A. M. Czopp, M. J. Monteith, and A. Y. Mark, "Standing Up for a Change: Reducing Bias through Interpersonal Confrontation,” Journal of Personality and Social Psychology 90, no. 5 (May 2006): $784-803$.

70 Cf. J. Greenberg, Sh. Solomon, and T. Pyszczynski, "The Cultural Animal: Twenty Years of Terror Management Theory and Research," in The Handbook of Experimental Existential Psychology, ed. J. Greenberg, S. L. Koole, and T. Pyszczynski (New York: Guilford, 2004), 13-34. 
plied to cases of individual voting preferences, stereotypic thinking and prejudice, which seems to be aroused by major social disruptions.

\section{Bibliography}

Ackerman, Nathan Ward, and Marie Jahoda. Anti-Semitism and Emotional Disorder: $A$ Psychoanalytic Interpretation. New York: Harper \& Brothers, 1950.

Adorno, Theodor W., Else Frenkel-Brunswik, Daniel J. Levinson, and Nevitt Sanford. The Authoritarian Personality. New York: Harper \& Brothers, 1950.

Allport, Gordon W. The Nature of Prejudice. Cambridge: Perseus Books, 1954.

Anti-Defamation League. "Attitudes Toward Jews and the Middle East in Five European Countries." Issued May 2007. https://www.adl.org/sites/default/files/documents/assets/ pdf/israel-international/European_Attitudes_Survey_May_2007.pdf.

Baigell, Matthew. The Implacable Urge to Defame: Cartoon Jews in the American Press, 1877-1935. Syracuse: Syracuse University Press, 2017.

Berkowitz, Leonard, and Douglas S. Holmes. "A Further Investigation of Hostility Generalization to Disliked Objects.” Journal of Personality 28 (December 1960): 427-42.

Blascovich Jim, Wendy Berry Mendes, Sarah B. Hunter, Brian Lickel, and Neneh Kowai-Bell. "Perceiver Threat in Social Interactions with Stigmatized Others." Journal of Personality and Social Psychology 80, no. 2 (2001): 253-67.

Bradshaw, Peter. "My Favorite Best Picture Oscar Winner: Gentleman's Agreement." The Guardian, February 15, 2017. https://www.theguardian.com/film/2017/feb/15/best-pic ture-oscar-winners-gentlemans-agreement-1947.

Breckler, Steven J. "Empirical Validation of Affect, Behavior, and Cognition as Distinct Components of Attitude." Journal of Personality and Social Psychology 47, no. 6 (1984): 1191-205.

Brewer, Marilynn B., and R. J. Brown. "Intergroup Relations." In The Handbook of Social Psychology, edited by Daniel T. Gilbert, Susan T. Fiske, and Lindzey Gardner, 554-94. New York: McGraw-Hill, 1998.

Castelli, Luigi, Leyla De Amicis, and Steven J. Sherman. "The Loyal Member Effect: On the Preference for Ingroup Members who Engage in Exclusive Relations with the Ingroup." Developmental Psychology 43, no. 6 (2007): 1347-59.

Cheng, Wen, William Ickes, and Jared B. Kenworthy. "The Phenomenon of Hate Crimes in the United States." Journal Of Applied Social Psychology 43, no. 4 (2013): 761-94.

Cohen, Florette, Lee Jussim, Kent D. Harber, and Gautam Bhasin. "Modern Anti-Semitism and Anti-Israeli Attitudes.” Journal of Personality and Social Psychology 97, no. 2 (2009): 290-306.

Cohen, Florette, Lee Jussim, Gautam Bhasin, and Elizabeth Ramzy Salib. "The New Anti-Semitism Israel Model: Real World Evidence and Experimental Tests." Conflict and Communication On-Line 10 (2011): 1-16.

Cohen, Jeffrey E. "Perceptions of Anti-Semitism among American Jews, 2000-05: A Survey Analysis." Political Psychology 31, no. 1 (February 2010): 85-107.

Czopp, Alexander M., Margo J. Monteith, and Aimee Y. Mark. "Standing Up for a Change: Reducing Bias through Interpersonal Confrontation." Journal of Personality and Social Psychology 90, no. 5 (May 2006): 784-803. 
Dee, David. “'There is no discrimination here, but the committee never elects Jews': Antisemitism in British Golf, 1894-1970." Patterns Of Prejudice 47, no. 2 (May 2013): $117-38$.

Devine, Patricia G. "Stereotypes and prejudice: Their Automatic and Controlled Components." Journal of Personality and Social Psychology 56, no. 1 (1989): 5-18.

Devine, Patricia G., and Andrew J. Elliot. "Are Racial Stereotypes Really Fading? The Princeton Trilogy Revisited." Personality and Social Psychology Bulletin 21 (1995): 1139-50.

Devine, Patricia G., and Margo J. Monteith. "Automaticity and Control in Stereotyping." In Dual-Process Theories in Social Psychology, edited by Shelly Chaiken and Yaakov Trope, 339-60. New York: Guilford, 1999.

Devine, Patricia G., Margo J. Montieth, Julia R. Zuwerink, and Andrew J. Elliot. "Prejudice with and without Compunction." Journal of Personality and Social Psychology 60, no. 6 (1991): $817-30$.

Dixon, John, and Kevin Durrheim. "Contact and the Ecology of Racial Division: Some Varieties of Informal Segregation.” British Journal of Social Psychology 42, no. 1 (March 2003): $1-23$.

Dollard, John. "Hostility and Fear in Social Life." Social Forces 17, no. 1. (October 1938): $15-26$.

Dutton, Donald G., and Robert A. Lake. "Threat of Own Prejudice and Reverse Discrimination in Interracial Situations." Journal of Personality and Social Psychology 28, no. 1 (1973): 94-100.

Festinger, Leon. “Informal Social Communication.” Psychological Review 57, no. 5 (1950): 271-82.

Gaertner, Samuel L., and John F. Dovidio. "The Aversive Form of Racism.” In Prejudice, Discrimination, and Racism, edited by Samuel L. Gaertner and John F. Dovidio, 61-90. San Diego: Academic Press, 1986.

Gerard, Harold B., and Norman Miller. School Desegregation: A Long-Term Study. New York: Plenum, 1975.

Glick, Peter Samuel. "Choice of Scapegoats." In On the Nature of Prejudice: Fifty Years after Allport, edited by John F. Dovidio, Peter Samuel Glick, and Laurie A. Rudman, 244-61. Malden: Blackwell, 2005.

Glock, Charles Y., and Rodney Stark. Christian Beliefs and Anti-Semitism. New York: Harper \& Row, 1966.

Gonen, Jan Y. A Psychohistory of Zionism. New York: New York American Library, 1975.

Greenberg, Jeff, Sheldon Solomon, and Tom Pyszczynski. "Terror Management Theory of Self-esteem." In Handbook of Social and Clinical Psychology: The Health Perspective, edited by C. R. Snyder and Donelson R. Forsyth, 21-40. Elmsford: Pergamon, 1991.

Greenberg, Jeff, Sheldon Solomon, and Tom Pyszczynski. "The Cultural Animal: Twenty Years of Terror Management Theory and Research." In The Handbook of Experimental Existential Psychology, edited by Jeff Greenberg, Sander L. Koole, and Tom Pyszczynski, 13-34. New York: Guilford, 2004.

Harber, Kent D. "Self-esteem and Affect as Information." Personality and Social Psychology Bulletin 31, no. 2 (February 2005): 276-88.

Hebl, Michelle R., Jessica Bigazzi Foster, Laura M. Mannix, and John F. Dovidio. "Formal and Interpersonal Discrimination: A Field Study of Bias Toward Homosexual Applicants." Personality and Social Psychology Bulletin 28, no. 6 (June 2002): 815-25. 
Hobson, Laura Z. Gentleman's Agreement. New York: Simon \& Schuster, 1947.

Hovland, Carl Iver, and Robert R. Sears. "Minor Studies in Aggression: VI. Correlation of Lynchings with Economic Indices.” Journal of Psychology 9 (1940): 301-10.

Iganski, Paul. "Too Few Jews to Count? Police Monitoring of Hate Crime against Jews in the United Kingdom.” American Behavioral Scientist 51, no. 2 (October 2007): 232-45.

Jackson, Lynne M. The Psychology of Prejudice: From Attitudes to Social Action. Washington: American Psychological Association, 2011.

Jacobs, Paul, and Saul Landau. To Serve the Devil: Natives and Slaves. New York: Random House, 1971.

Jones, Edward E., Amerigo Farina, Albert H. Hastorf, Hazel Markus, Dale T. Miller, and Robert A. Scott. Social Stigma: The Psychology of Marked Relationships. New York: Freeman, 1984.

Jones, James M. Prejudice and Racism. New York: McGraw-Hill, 1996.

Kelman, Herbert C. "Transforming the Relationship between Former Enemies: A Social Psychological Analysis." In After the Peace: Resistance And Reconciliations, edited by Robert L. Rothstein, 193-205. London: Lynne Renner, 1999.

Kohl, Diane. "The Presentation of 'Self' and 'Other' in Nazi Propaganda." Psychology and Society 4, no. 1 (2011): 7-26.

Leach, Colin Wayne, Anca Minescu, Edwin Poppe, Louk Hagendoorn, Andrea E. Abele, Amy J. C. Cuddy, Charles M. Judd, and Vincent Y. Yzerbyt. "Generality and Specificity in Stereotypes of Out-group Power and Benevolence: Views of Chechens and Jews in the Russian Federation.” European Journal Of Social Psychology 38, no. 7 (December 2008): $1165-74$.

Lerner, Melvin. The Belief in a Just World: A Fundamental Decision. New York: Plenum, 1980. Lerner, Melvin, and Dale T. Miller. "Just World Research and the Attribution Process: Looking Back and Ahead." Psychological Bulletin 85, no. 5 (1978): 1030-51.

Levinson, Daniel J., and R. Nevitt Sanford. "A Scale for the Measurement of Anti-Semitism." The Journal of Psychology 17, no. 2 (1944): 339-70.

Lewis, Bernard. “The New Anti-Semitism.” American Scholar 75 (2006): 25-36. Lippmann, Walter. Public Opinion. New York: Harcourt, Brace and Company, 1922.

Maass, Anne, Francesca Montalcini, and Elisa Biciotti. "On the (Dis-)confirmability of Stereotypic Attributes.” European Journal Of Social Psychology 28, no. 3 (May 1998): $383-402$.

McConahay, John B. “Modern Racism, Ambivalence, and the Modern Racism Scale." In Prejudice, Discrimination, and Racism, edited by Samuel L. Gaertner and John F. Dovidio, 91-125. San Diego: Academic Press, 1986.

Mohl, Allan. "The Evolution of Anti-Semitism: Historical and Psychological Roots." The Journal Of Psychohistory 39, no. 2 (2011): 115-28.

Mollov, Ben. "The Role of Religion in Conflict Resolution: An Israeli-Palestinian Student Dialogue." Jerusalem Letter / Viewpoints 404 (April 1999): 1-6.

Monteith, Margo J., Leslie Ashburn-Nardo, Corrine I. Voils, and Alexander M. Czopp. "Putting the Brakes on Prejudice: On the Development and Operation of Cues for Control." Journal of Personality and Social Psychology 83, no. 5 (2002): 1029-50.

Monteith, Margo J. "Self-regulation of Prejudiced Responses: Implications for Progress in Prejudice Reduction Efforts." Journal of Personality and Social Psychology 65, no. 3 (1993): 469-85. 
Morse, Nancy C., and Floyd H. Allport "The Causation of anti-Semitism: An Investigation of Seven Hypotheses." The Journal of Psychology: Interdisciplinary and Applied 34 (1952): 197-233.

Mozgovaya, Natasha. "Poll: 31\% of Europeans Blame Jews for Global Financial Crisis." Haaretz, February 10, 2009. https://www.haaretz.com/1.5073513.

N.N. "Anti-Israel Protests Call For 'Death to Israel' \& 'Resistance'." Anti-Defamation League Blog, July 10, 2014. https://www.adl.org/blog/anti-israel-protests-call-for-death-to-israelresistance.

N.N. "UN Security Council Resolution 1701." Haaretz, November 26, 2007. https://www.haar etz.com/1.4960375.

Nafie, Ibrahim. “Israel's anti-Semitism.” Al-Ahram Weekly Online, November 20-26, 2003. http://weekly.ahram.org.eg/2003/665/op1.htm.

Nelson, Todd D. The Psychology of Prejudice. Boston: Allyn \& Bacon, 2002.

Oppenheim, Maya. "Roald Dahl after 100 Years: Remembering Beloved Author's Forgotten Anti-Semitic Past." Independent Minds, September 13, 2016. https://www.independent. co.uk/news/people/roald-dahl-antisemitic-100-years-remembering-author-forgotten-pasta7254266.html.

Ostow, Mortimer. "A Contribution to the Study of Antisemitism." In Error without Trial: Psychological Research on Antisemitism, edited by Werner Bergmann, 52-76. Berlin: de Gruyter, 1988.

Pettigrew, Thomas F. “Intergroup Contact Theory.” Annual Review of Psychology 49, no. 1 (1998) 68-85.

Pettigrew, Thomas F. "Personality and Sociocultural Factors in Intergroup Attitudes: a Cross-national Comparison.” Journal of Conflict Resolution 2, no. 1 (March 1958): 29-42.

Pettigrew, Thomas F., and Roel W. Meertens. "Subtle and Blatant Prejudice in Western Europe.” European Journal of Social Psychology, 25 (1995): 57-75.

Porat, Dina, Roni Stauber, and Raphael Vago, eds. Anti-Semitism Worldwide 2003/4. Tel Aviv: The Stephen Roth Institute, Tel Aviv University, 2005.

Richeson, Jennifer A., and J. Nicole Shelton. "When Prejudice Does Not Pay: Effects of Interracial Contact on Executive Function." Psychological Science 14, no. 3 (May 2003): 287-90.

Rogers, Ronald W., and Steven Prentice-Dunn. "Deindividuation and Anger-mediated Interracial Aggression: Unmasking Regressive Racism." Journal of Personality and Social Psychology 41, no. 1 (July 1981): 63-73.

Rokeach, Milton, and Louis Mezei. "Race and Shared Belief as Factors in Social Choice." Science 151, no. 3707 (1966): 167-72.

Rudman, Laurie A., Richard D. Ashmore, and Melvin L. Gary. “'Unlearning” Automatic Biases: The Malleability of Implicit Prejudice and Stereotypes." Journal of Personality and Social Psychology 81, no. 5 (2001): 856-68.

Sartre, Jean-Paul. Anti-Semite and Jew. New York: Schocken Press, 1948.

Şerif, Muzaffer. Group Conflict and Cooperation: Their Social Psychology. London: Routledge \& Kegan, 1966.

Şerif, Muzaffer, et al. The Robbers Cave Experiment: Intergroup Conflict and Cooperation. Middletown: Wesleyan University Press, 1961. 
Smith, Christian, and Robert Faris. "Socioeconomic Inequality in the American Religious System: An Update and Assessment." Journal for the Scientific Study of Religion 44 (2005): 95-104.

Spunberg, Jorge. "History of the Jews in Poland." Accessed June 5, 2018. http://www.berdi chev.org/history_of_the_jews_in_poland.htm.

Swim, Janet K., Kathryn J. Aikin, Wayne S. Hall, and Barbara A. Hunter. "Sexism and Racism: Old-fashioned and Modern Prejudices." Journal of Personality and Social Psychology 68, no. 2 (1995): 199-214.

Taifel, Henri. “Social Psychology of Intergroup Relations.” Annual Reviews of Psychology 33, no. 1 (1982): 1-39.

U.S. Census. "Law Enforcement, Courts, and Prisons." Accessed June 25, 2018. http://www. census.gov/prod/2004pubs/04statab/law.pdf.

Vallone, Robert P., Lee Ross, and Mark R. Lepper. "The Hostile Media Phenomenon: Biased Perception and Perceptions of Media Bias in Coverage of the Beirut Massacre." Journal of Personality and Social Psychology 49, no. 3 (1985): 577-85.

Weber, Max. Protestant Ethic and the Spirit of Capitalism. New York: Scribner, 1958.

Weatherley, Donald. "Antisemitism and the Expression of Fantasy Aggression." The Journal of Abnormal and Social Psychology 62, no. 2 (1961): 454-57.

Wood, Wendy. "Attitude Change: Persuasion and Social Influence." Annual Review of Psychology 51 (2000): 539-70.

Zimmermann, Moshe. Wilhelm Marr: The Patriarch of Anti-semitism. New York: Oxford University Press, 1986. 